\title{
Assessment and Comparison of SPI and RDI Meteorological Drought Indices in Panchmahals District of Gujarat, India
}

\author{
A.V. Memon ${ }^{1 *}$ and N.V. Shah ${ }^{2}$ \\ ${ }^{1}$ Department of Basic Engineering and Applied Science, College of Agriculture Engineering \\ and Technology, Anand Agriculture University, Godhra, India \\ ${ }^{2}$ Department of Food Engineering, College of Food processing Technology and Bio Energy, \\ Anand Agriculture University, Anand, India \\ *Corresponding author
}

\section{A B S T R A C T}

\section{Keywords}

Drought, Meteorological drought, Drought indices, Standardized

Precipitation Index (SPI), Reconnaissance Drought Index (RDI)

Article Info

Accepted:

15 July 2019

Available Online:

10 August 2019
Drought is one of the natural disasters of tremendous significance owing to intensity, duration, magnitude, financial damage and long-term impacts in comparison with other disasters. The evaluation of drought is aimed at identifying the onset, continuity and severity of drought. Reliable surveillance of drought and early warning are essential in preparing for drought, planning and mitigating future effects, particularly early warnings of famine. In present study, meteorological drought indices such as the Standardized Precipitation Index (SPI) and the Reconnaissance Drought Index (RDI) were used for drought assessment in Panchmahals district of Gujarat state for period of 99 years (1900 1999). The objective of the study was to supervise and compare the drought using SPI and RDI. The results of this study showed that the RDI is more sensitive than the SPI to climatic conditions and so we can't neglect the role of evapotranspiration in drought assessments. The results also showed that both indices behave in the same manner, but RDI due to use of potential evapotranspiration in similar climatic conditions is more sensitive. Based on the findings of this research, it is suggested that the RDI index be used as the appropriate drought index for water resource planning and management in drought surveillance schemes.

\section{Introduction}

Drought is a complicated natural phenomenon and has a major impact on the efficient management of water resources. Overall, drought provides an impression of water scarcity owing to inadequate precipitation, excessive evapotranspiration and overuse of water resources or a conjunction of all of the above. The definition of drought is slightly different from viewpoints of different experts. For example, for a meteorologist it is a deviation from normal precipitation; for a hydrologist a fall in stream flow, lake level, or groundwater level; for an agricultural scientist lack of soil moisture to sustain crop growth; for an economist a famine condition; and for an urbanite shortage of tap water supply [5]. There are three main drought categories, i.e., meteorological, hydrological and agricultural 
droughts. The meteorological drought is articulated exclusivelyon the basis of the dryness measured in terms of deficiency in rainfall. On the other side, hydrological drought is described on the basis of lack of water availability in terms of stream flow, storage of reservoirs and depths of groundwater. The agricultural drought is expressed based on soil moisture deficits, and considers rainfall deficits, soil water deficits, variation of evapotranspiration etc. The precipitation is the principal parameter for many drought indices. However, based on recent reports by the Intergovernmental Panel on Climate Change [6, 7]. The observed climate variability for various meteorological parameters (e.g. precipitation, temperature) follows different patterns in several regions of the world. Additionally, the regional characteristics of droughts are expected to change, as a result of the variation of meteorological parameters or due to the cumulative adverse effect of more than one parameter (e.g. decrease of precipitation and increase of temperature) [8]. Therefore, indices that incorporate temperature in their formulation are considered more appropriate for representing the climate change conditions [12]. In the present study, drought assessment was carried out using the Standardized Precipitation Index (SPI) and Reconnaissance Drought Index (RDI) for Panchmahals district of Gujarat state and also the comparison between SPI and RDI for different time scales i: e 3, 6, 9 and 12 months were carried out.

\section{Study area and data collection}

The study area is Panchmahals district of Gujarat state. Panchmahals, is a district in the eastern portion of Gujarat State western India. The district is located on eastern end of the state. It is bordered by Dahod District to the north-east, Vadodara District to the south-west and Chhota Udaipur District to south-east, Kheda District to the west and Mahi sagar
District to the north. Panchmahals district is further divided in 7 Taluka's i.e. Godhra, Halol, Kalol, Jambughoda, Shahera, Morva, Hadaf, and Goghamba for administrative purposes. The data required for the present study were precipitation, maximum and minimum temperature from 1900 to 1999 , which were collected from Indian Meteorological Department, Pune (Fig. 1).

\section{Materials and Methods}

The method seeks to get an understanding of the severity and length of drought by tracking and evaluating the meteorological drought in the district of Panchmahals by comparing the indices of Standardized Precipitation (SPI) and Reconnaissance Drought (RDI) to assess their efficiency.

\section{Standardized Precipitation Index}

McKee et al., [14] intended it to quantify the rainfall deficit. The calculation of the SPI is based on the values of precipitation over a long period of time. A long-term study area precipitation record is first fitted to the probability distribution to calculate the SPI, which is then transformed into a normal distribution so that the mean SPI value becomes zero. The SPI has the following favourable characteristics: (a) it is uniquely related to probability; (b) the precipitation used in the SPI can be used to calculate the current period's precipitation deficit and the current percentage of average precipitation over a period of I months; and (c) the SPI is normally distributed so that it can be used to monitor both wet and dry periods.

Mathematically,

$S P I=\frac{x_{i j}-\bar{x}}{\sigma}$.

Where, $x_{i j}=$ precipitation at $i^{\text {th }}$ rain gauge and $\mathrm{j}^{\text {th }}$ observation 
$\bar{x}=$ long term seasonal mean

$\sigma=$ standard deviation.

When the value of SPI reaches to -1 or less, a drought occurs. Similarly, when SPI reaches to positive value, a drought ends.

\section{Reconnaissance drought index}

Based on the cumulative equantity of precipitation and potential evapotranspiration, RDI was designed by Tsakiris et al., [3].

$\alpha_{0}^{(i)}=\frac{\sum_{j=1}^{1 n} \mathrm{P}_{\mathrm{ij}}}{\sum_{j=1}^{12} \text { PETij }^{1}} \mathrm{i}=1: \mathrm{N}$ and $\mathrm{j}=1: 12 \ldots$

Where, Pij and PETij are precipitation values and potential evapotranspiration of month $i$ and year $\mathrm{j}$, respectively. If the scale of the study is based on year, then the value of $j$ is from 1 to 12. Parameter $\mathrm{N}$ is the number of years with statistics. The current approach for calculating evapotranspiration is the Thorn thwaite equation as this equation indicates the quantities of evapotranspiration in arid and semi-arid regions below the real amount.

In the second step, RDI values were calculated by $\propto_{0}^{(i)}$ for different years and then were normalized $\left(R D I_{n}^{(i)}\right)$ as,

$R D I_{n}^{(i)}=\frac{\alpha_{0}^{(i)}}{\bar{a}_{0}}-1$

Where, $\bar{a}_{0}$ is the arithmetic mean of $\propto_{0}^{(i)}$ values for different years that are equal to the Drought Index ratio provided by FAO.

Then in the final step, standardized RDI values $\left(R D I_{s t}\right)$ were calculated using the $\alpha_{0}^{(i)}$ values for different years, assuming that the $\propto_{0}^{(i)}$ values follow the log-normal distribution.
$R D I_{s t}^{(i)}=\frac{y^{(\mathbb{1})}-\bar{y}}{\hat{\sigma}_{y}}$

Where $y^{(i)}$ equals to $\ln \left({ }^{\propto}{ }^{\wedge} 0^{\wedge}((i))\right), \bar{y}$ and $\hat{\sigma}_{y}$ are arithmetic mean and standard deviation of $y^{(i)}$, respectively.

\section{Results and Discussion}

For the Panchmahals district, according to SPI 3 mild drought was observed 28 times, moderate drought 15 times and 7 times severe drought. For SPI 6 mild drought was observed 37 times, moderate drought 8 times and 8 times severe drought. For SPI 9 mild drought was observed 24 times, moderate drought 9 times and 10 times severe drought. For SPI 12 mild drought was observed 34 times, moderate drought 5 times and 10 times severe drought. Table 3 shows they ears impacted by drought as per SPI (Fig. 2-5).

For the Panchmahals district, the RDI 3 mild drought was observed 7 times, moderate drought 9 times, extreme drought 4 times and8 times severe drought. For RDI 6 mild drought was observed 14 times, moderate drought 6 times, extreme drought 3 times and 5 times severe drought. For RDI 9 mild drought was observed 9 times, moderate drought 5 times, extreme drought 4 times and 6 times severe drought.

For RDI 12 mild drought was observed 11 times, moderate drought 4 times, extreme drought 5 times and 6 times severe drought. Table 4 shows they ears impacted by drought as per RDI (Fig. 6-10; Table 1 and 2).

\section{Comparison between SPI and RDI for different time scales}

Figures 11 to 13 show comparison between the outputs of SPI and RDI based on the time scales of 3, 6, 9 and 12 months from 1900 to 1999 years. 
Table.1 Classification of SPI Values

\begin{tabular}{|c|c|}
\hline Description & Classification \\
\hline $\mathbf{2}$ or more & Extremely wet \\
\hline $\mathbf{1 . 5}$ to 1.99 & Severely wet \\
\hline $\mathbf{1 . 0}$ to 1.49 & Moderately wet \\
\hline $\mathbf{- 0 . 9 9}$ to 0.99 & Near normal \\
\hline $\mathbf{- 1 . 0}$ to $-\mathbf{1 . 4 9}$ & Moderately dry \\
\hline $\mathbf{- 1 . 5}$ to $-\mathbf{1 . 9 9}$ & Severely dry \\
\hline-2 or less & Extremely dry \\
\hline
\end{tabular}

Table.2 Classification of RDI Values

\begin{tabular}{|c|c|}
\hline RDI Value & Classification \\
\hline $\mathbf{- 0 . 5}$ to $-\mathbf{1 . 0}$ & Mild \\
\hline $\mathbf{- 1 . 0}$ to -1.5 & Moderately dry \\
\hline $\mathbf{- 1 . 5}$ to $-\mathbf{2 . 0}$ & Severely dry \\
\hline $\mathbf{- 2}$ or less & Extremely dry \\
\hline
\end{tabular}

Table.3 Years affected by drought in Panchmahals district according to SPI 3

\begin{tabular}{|c|c|c|c|c|}
\hline & SPI 3 & SPI 6 & SPI 9 & SPI 12 \\
\hline Moderate & $1902-1903,1905-$ & $1904-$ & $1901-$ & $1900-$ \\
drought & $1906,1906-1907,1917$ & $1905,1906-$ & $1902,1904-$ & $1901,1903-$ \\
& $-1918,1920-$ & $1907,1912-$ & $1905,1920-$ & $1904,1971-$ \\
& $1921,1922-1923,1925$ & $1913,1919-$ & $1921,1925-$ & $1972,1984-$ \\
& $-1926,1936-$ & $1920,1922-$ & $1926,1948-$ & $1985,1994-$ \\
& $1937,1938-1939,1941$ & $1923,1969-$ & $1949,1950-$ & 1995, \\
& $-1942,1944-$ & $1970,1983-$ & $1951,1961-$ & \\
& $1945,1952-1953,1963$ & $1984,1985-$ & $1962,1971-$ & \\
\hline Severe & $-1964,1964-$ & 1986 & $1972,1994-$ & \\
drought & $1965,1988-1989$ & & 1995 & $1910-$ \\
& $1904-1905,1907-$ & $1902-$ & $1902-$ & $191,1914-$ \\
& $-1941,1949-$ & $1918,1920-$ & $1907,1922-$ & $1915,1917-$ \\
& $1950,1951-1952,1971$ & $1921,1944-$ & $1923,1938-$ & $1918,1922-$ \\
& -1972 & $1945,1949-$ & $1939,1940-$ & $1923,1950-$ \\
& & $1950,1951-$ & $1941,1946-$ & $1951,1964-$ \\
& & $1952,1963-$ & $1947,1949-$ & $1965,1965-$ \\
& & $1964,1971-$ & $1950,1964-$ & $1966,1967-$ \\
& & 1972 & $1965,1967-$ & $1968,1973-$ \\
& & & $1968,1983-$ & $1974,1986-$ \\
\hline
\end{tabular}


Table.4 Years affected by drought in Panchmahals district according to RDI

\begin{tabular}{|c|c|c|c|c|}
\hline & RDI 3 & RDI 6 & RDI 9 & RDI 12 \\
\hline $\begin{array}{l}\text { Moderate } \\
\text { drought }\end{array}$ & $\begin{array}{l}1905-1906, \\
1906-1907, \\
1917-1918, \\
1920-1921, \\
1925-1926, \\
1936-1937, \\
1938-1939, \\
1963-1964, \\
1988-1989\end{array}$ & $\begin{array}{c}1904- \\
1905,1912- \\
1913,1919- \\
1920,1969- \\
1970,1983- \\
1984,1985- \\
1986,\end{array}$ & $\begin{array}{c}1904- \\
1905,1906- \\
1907,1925- \\
1926,1948- \\
1949,1994- \\
1995\end{array}$ & $\begin{array}{c}1903- \\
1904,1971- \\
1972,1984- \\
1985,1994- \\
1995\end{array}$ \\
\hline $\begin{array}{l}\text { Extreme } \\
\text { Drought }\end{array}$ & $\begin{array}{c}1904-1905, \\
1919-1920, \\
1951-1952, \\
1971-1972\end{array}$ & $\begin{array}{c}1902- \\
1903,1949- \\
1950,1951- \\
1952\end{array}$ & $\begin{array}{c}1922- \\
1923,1949- \\
1950,1964- \\
1965,1983- \\
1984\end{array}$ & $\begin{array}{c}1910- \\
1911,1914- \\
1915,1917- \\
1918,1973- \\
1974,1986- \\
1987\end{array}$ \\
\hline $\begin{array}{l}\text { Severe } \\
\text { drought }\end{array}$ & $\begin{array}{c}1902-1903, \\
1907-1908, \\
1922-1923, \\
1940-1941, \\
1941-1942, \\
1944-1945, \\
1949-1950, \\
1952-1953\end{array}$ & $\begin{array}{c}1917- \\
1918,1920- \\
1921,1944- \\
1945,1963- \\
1964,1971- \\
1972\end{array}$ & $\begin{array}{c}1901- \\
1902,1902- \\
1903,1938- \\
1939,1940- \\
1941,1946- \\
1947,1967- \\
1968\end{array}$ & $\begin{array}{c}1900- \\
1901,1922- \\
1923,1950- \\
1951,1964- \\
1965,1965- \\
1966,1967- \\
1968\end{array}$ \\
\hline
\end{tabular}

Figure.1 Study Area \& Data collection
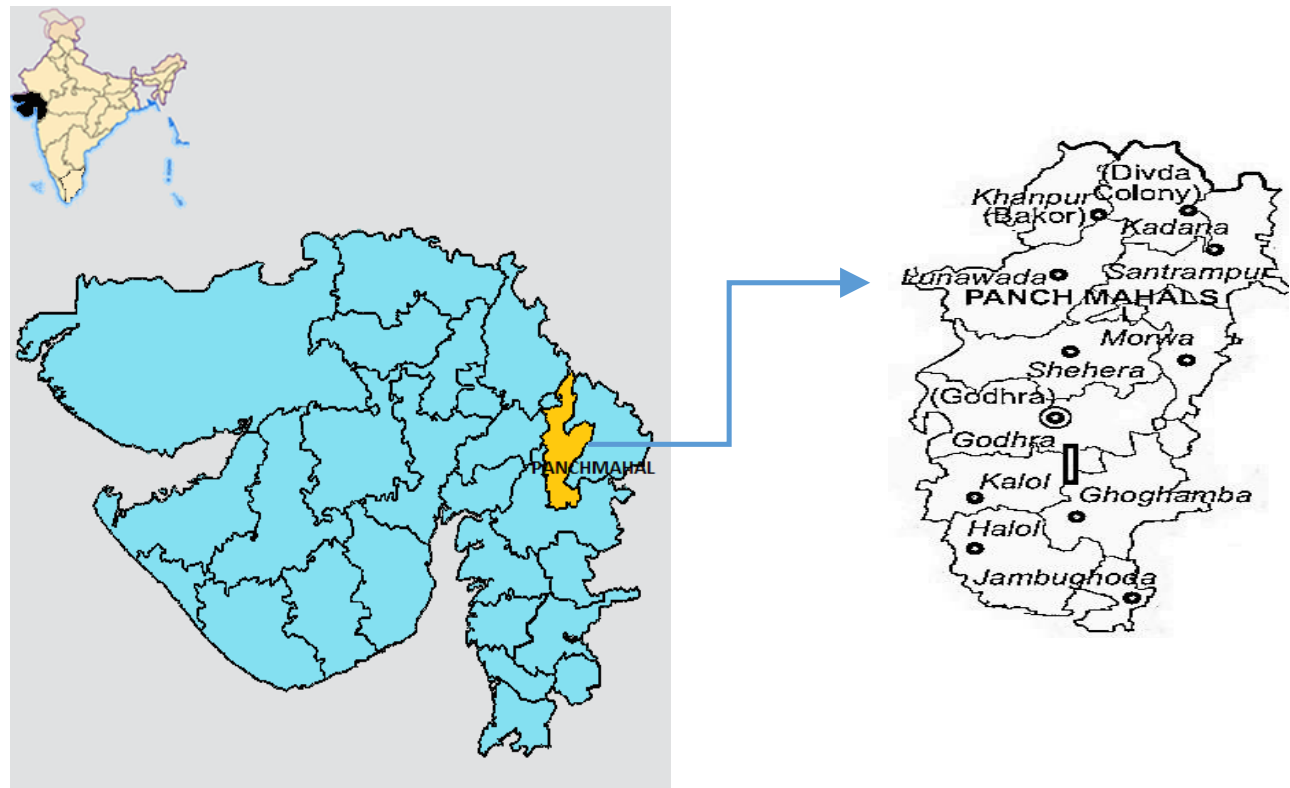
Figure 2. SPI for 3 months' time scale SPI 3

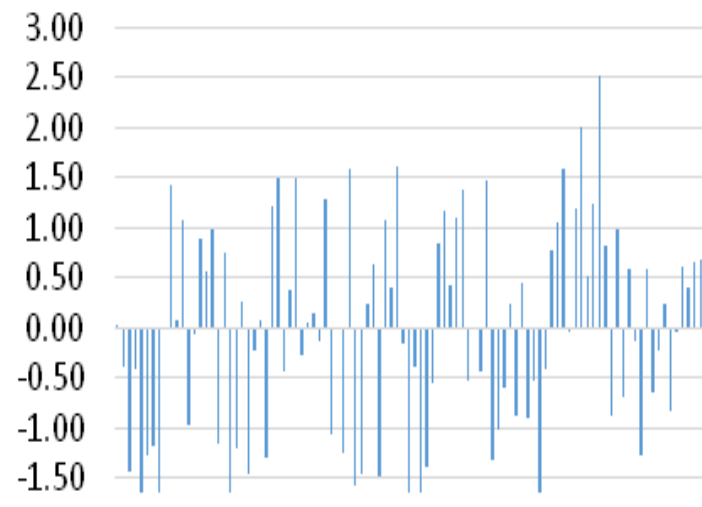

$-2.00$

Figure 3. SPI for 6 months' time scale

SPI6

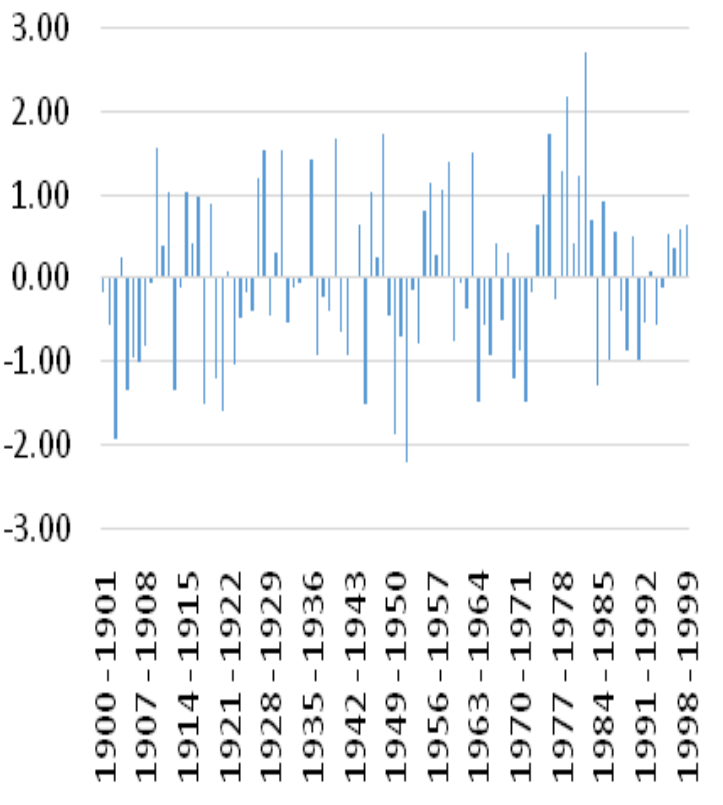

Figure 4. SPI for 9 months' time scale

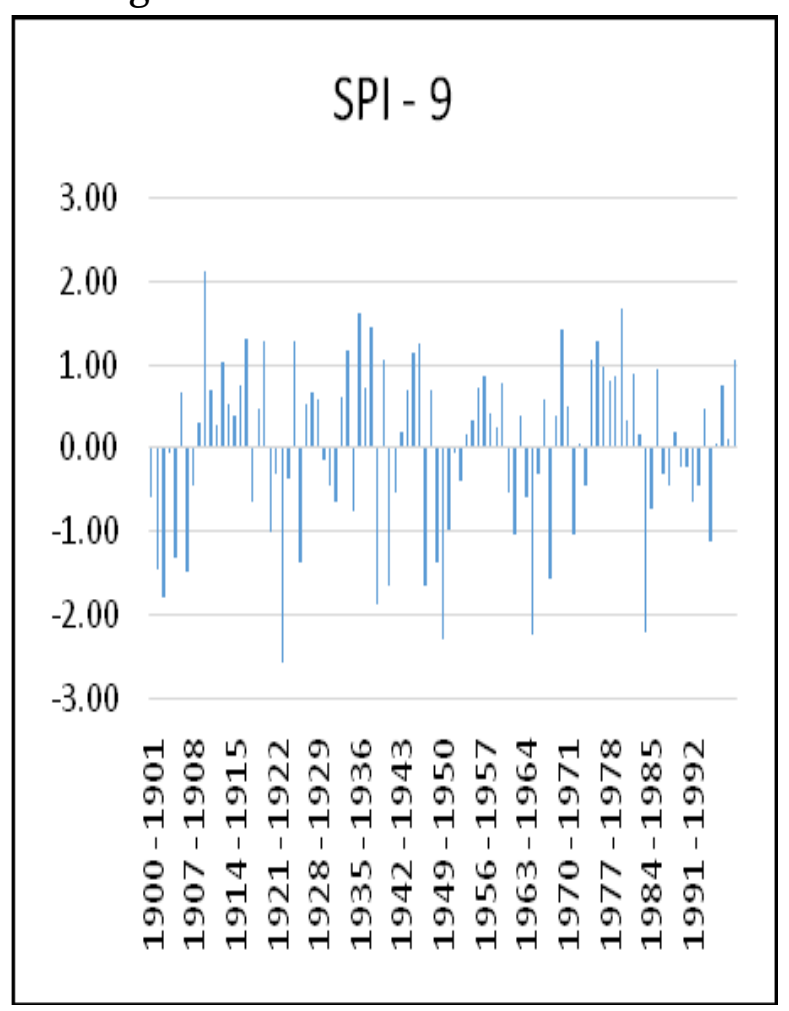

Figure 5. SPI for 12 months' time scale

\section{SPI 12}

3.00

2.00

1.00

0.00

$-1.00$

$-2.00$

$-3.00$

ब $\sigma \sigma \sigma \sigma \sigma \sigma \sigma \sigma \sigma \sigma \sigma \sigma$

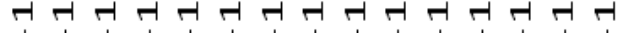

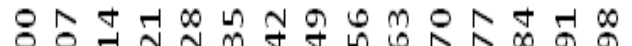
ด유 
Figure 6.RDI for 3 month time scale

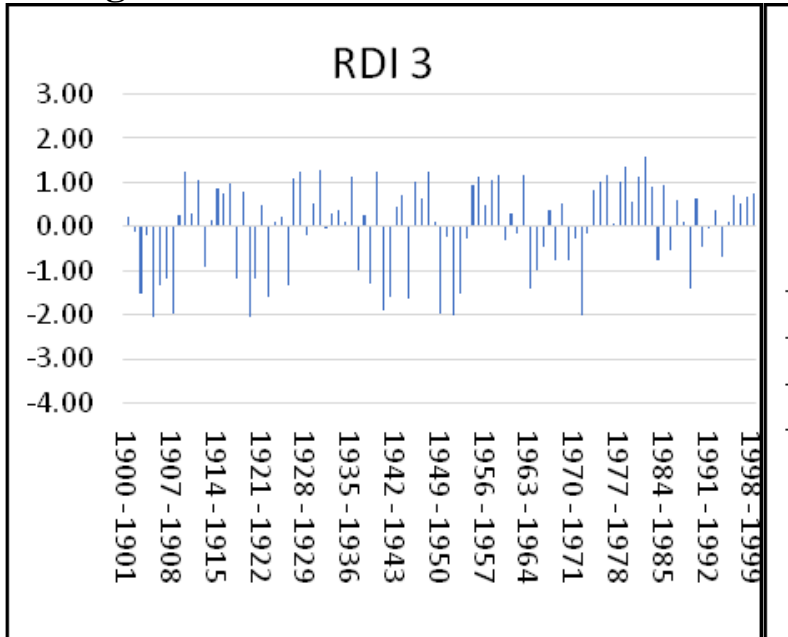

Figure 7.RDI for 6 month time scale

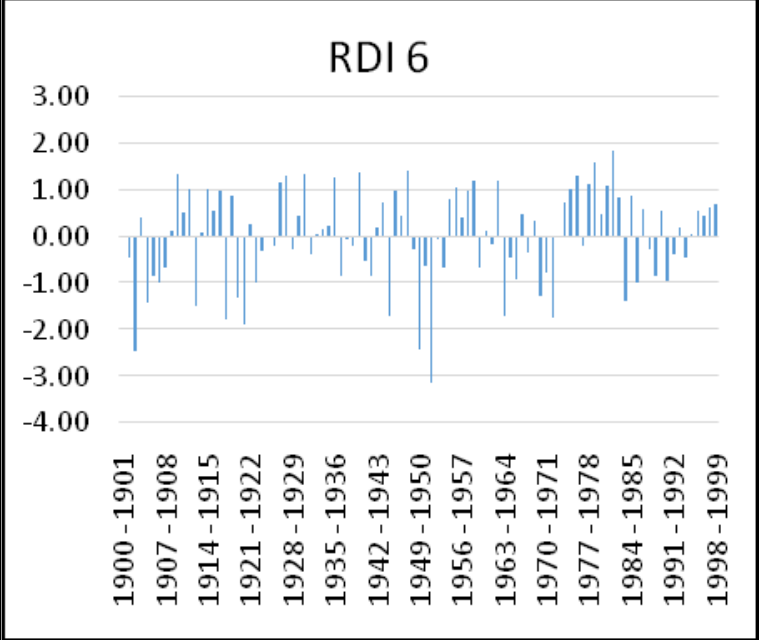

Figure 8. RDI for 9 month time scale

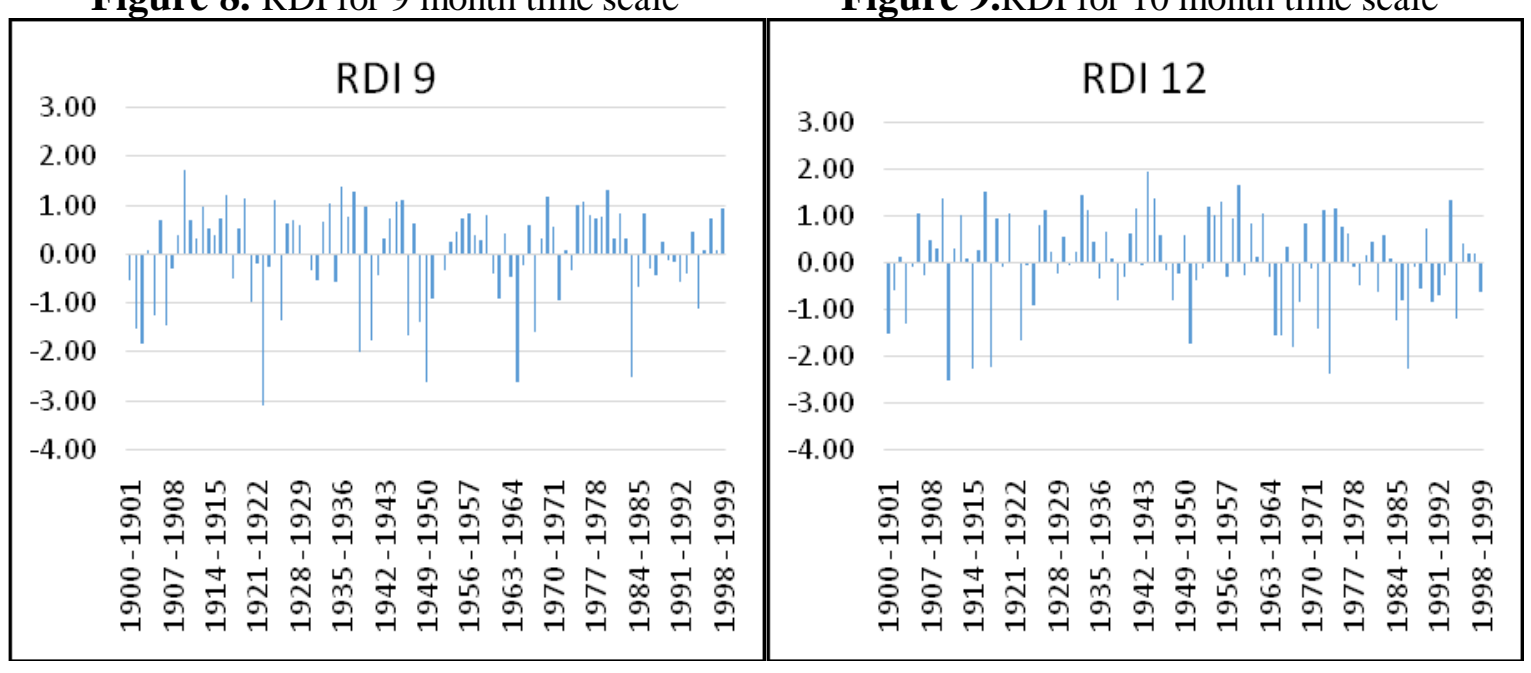

Fig.10 Comparison of SPI and RDI 3 months' time series for Panchmahals district in period (1900-1999)

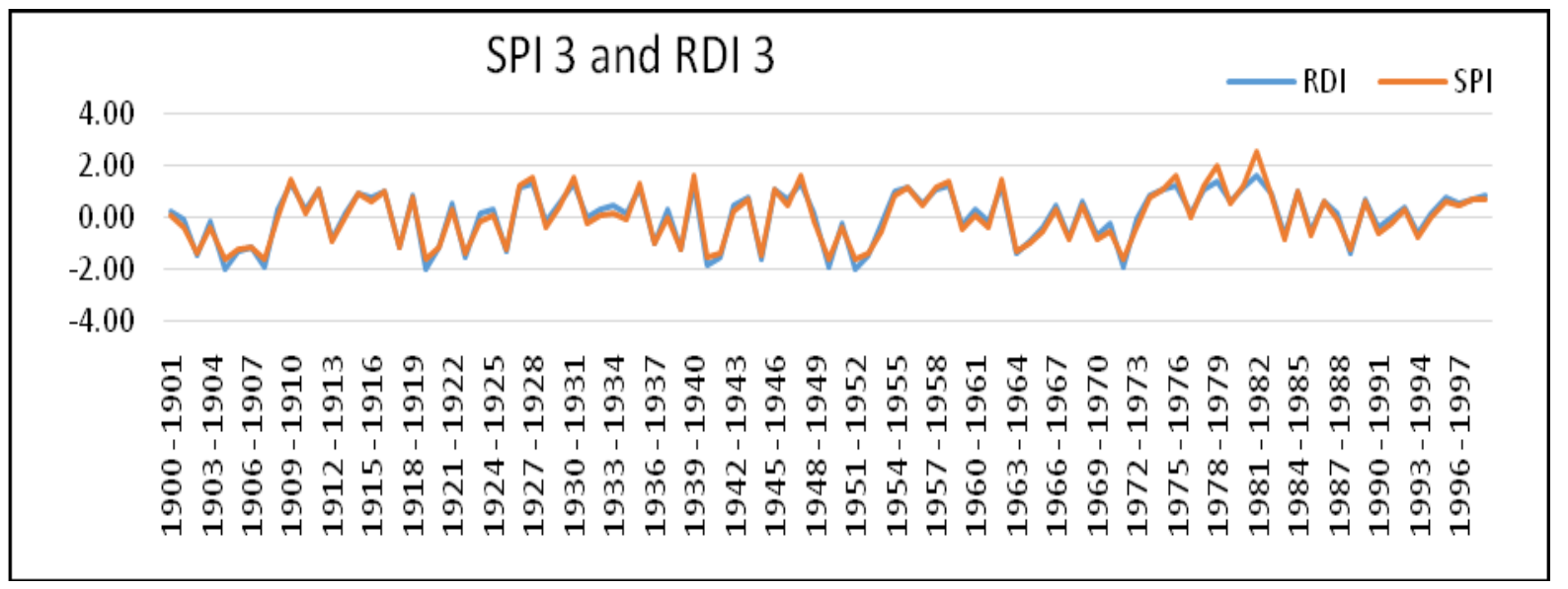


Fig.11 Comparison of SPI and RDI 6 months' time series for Panchmahals district in period (1900-1999)

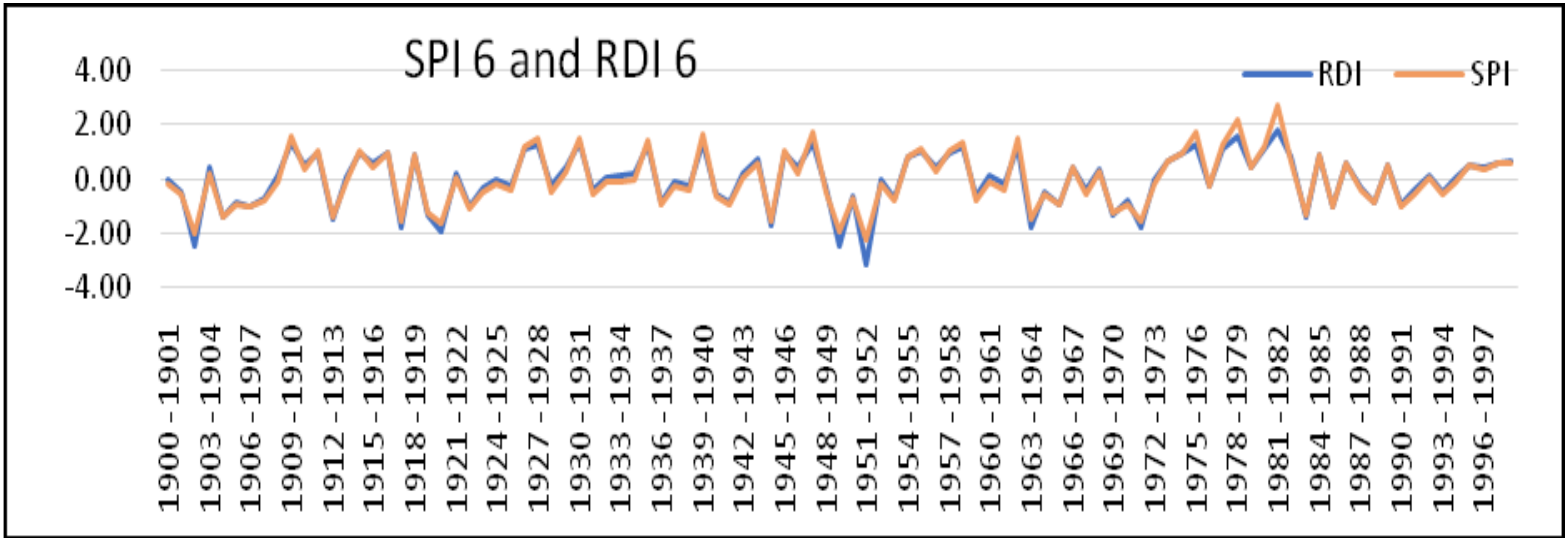

Fig.12 Comparison of SPI and RDI 9 months' time series for Panchmahals district in period (1900-1999)

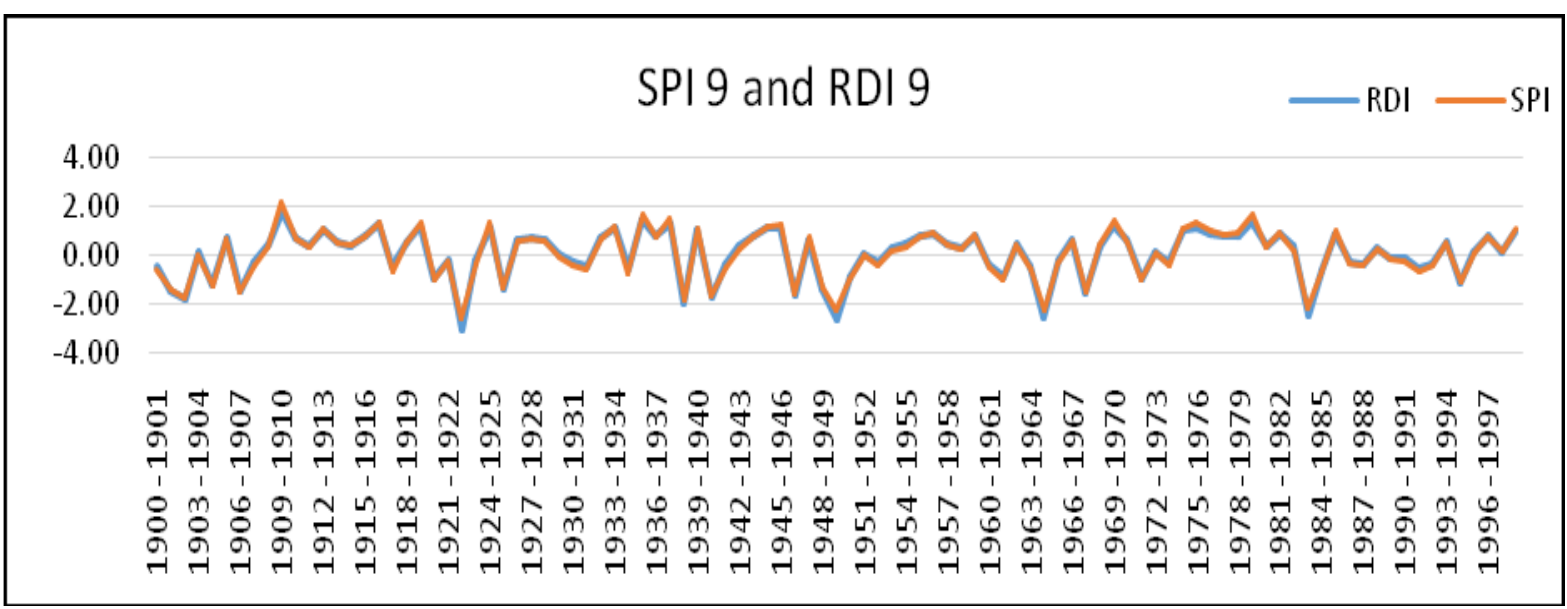

Fig.13 Comparison of SPI and RDI 12 months' time series for Panchmahals district in period (1900-1999)

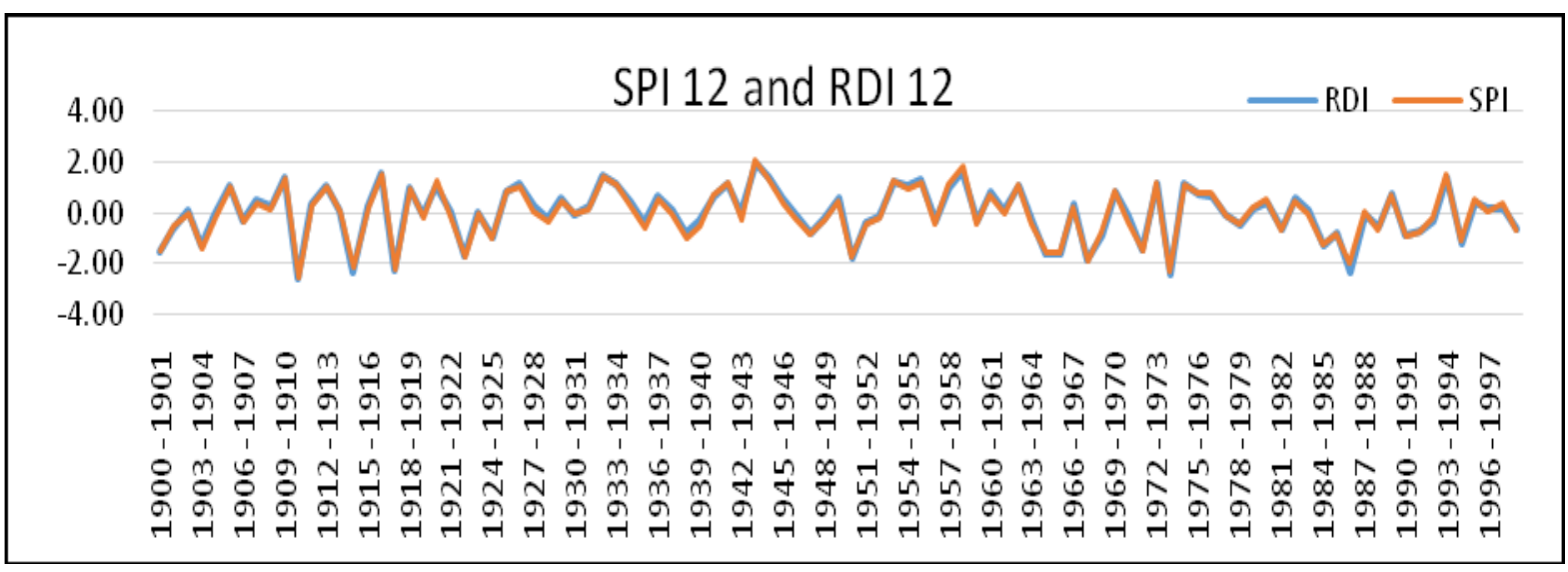


Fig.14 Correlation between SPI and RDI based on 3, 6, 9 and 12 -months' time series for Panchmahals district in period (1900-1999)
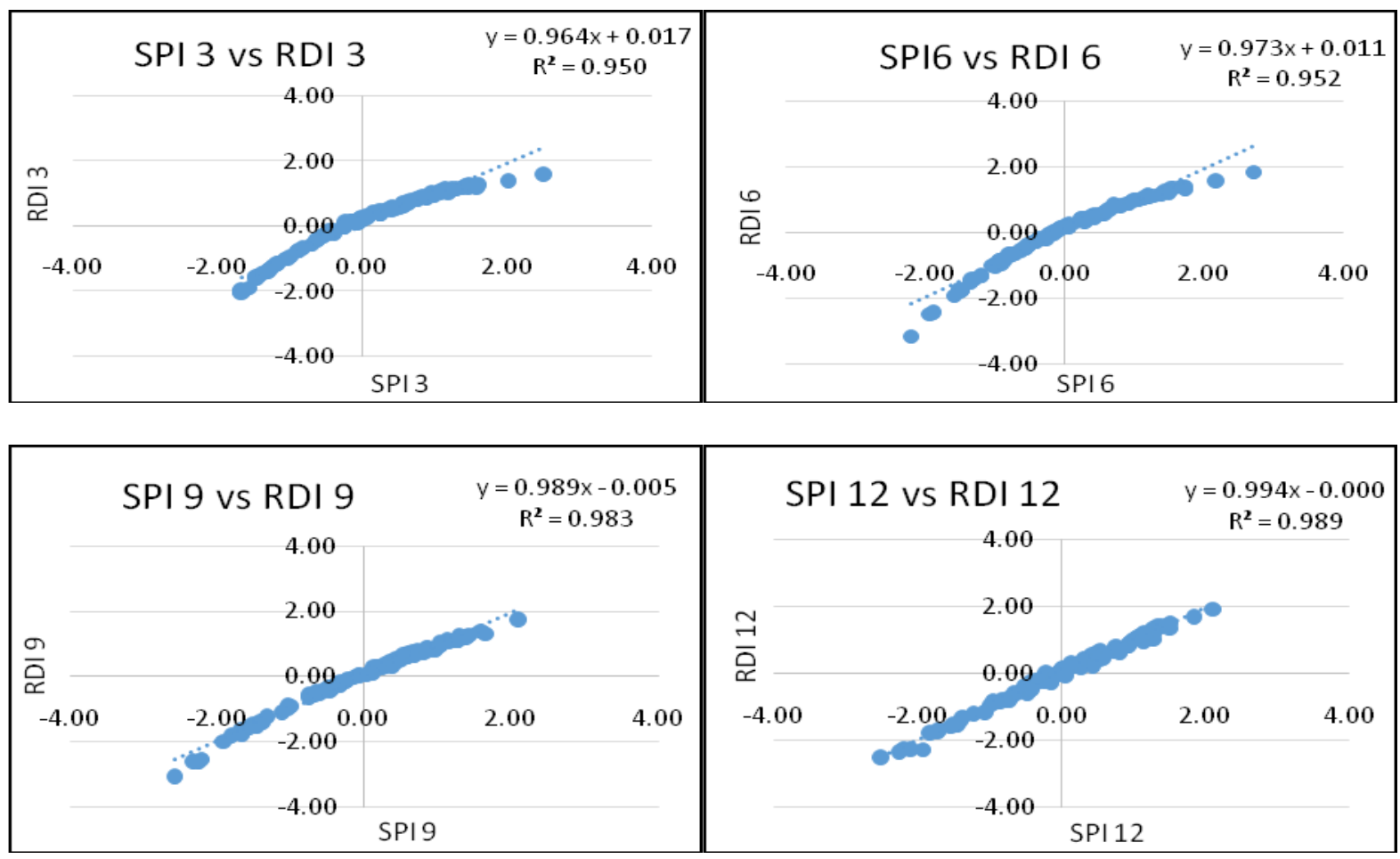

Results of these correlation analyses generally revealed that there is good relationship between the SPI and RDI indices in all time scales. The higher the time scale of analysis, the stronger the relationship is seen.

The coefficient of determination $\left(\mathrm{R}^{2}\right)$ between SPI and RDI was noted that it increased from 0.904 for the 3-month time scale to 0.9896 for the 12 month time scale shown in figure 14.

According to SPI 3 mild drought was observed 28 times, moderate drought 15 times and 7 times severe drought. For SPI 6 mild drought was observed 37 times, moderate drought 8 times and 8 times severe drought. For SPI 9 mild drought was observed 24 times, moderate drought 9 times and 10 times severe drought. For SPI 12 mild drought was observed 34 times, moderate drought 5 times and 10 times severe drought.

According to RDI 3 mild drought was observed 7 times, moderate drought 9 times, extreme drought 4 times and8 times severe drought. For RDI 6 mild drought was observed 14 times, moderate drought 6 times, extreme drought 3 times and 5 times severe drought. For RDI 9 mild drought was observed 9 times, moderate drought 5 times, extreme drought 4 times and 6 times severe drought. For RDI 12 mild drought was observed 11 times, moderate drought 4 times, extreme drought 5 times and 6 times severe drought.

The correlation analyses generally revealed that there is good relationship between the SPI and RDI indices in all time scales. The coefficient of determination $\left(\mathrm{R}^{2}\right)$ between SPI and RDI was observed that it increased from 0.904 for the 3month time scale to 0.9896 for the 12 month time scale.

In this study it was observed that the indices calculated at a longer times scales i:e 12 months provided better results as longer time scale reflects better historical drought. Based on the present study findings of this research, it is 
recommended that the RDI index should be used as the proper drought index in drought monitoring systems for water resources planning and management. In addition, any drought index is only helpful to the extent that it can be trusted in the input information used to calculate it.

\section{References}

Dracup, J. A., Lee, K. S., and Paulson, E. N., Jr. (1980). On the statistical characteristics of drought events. Water Resource. Res., 16(2): 289-296.

F.A. Al-Faraj, M. Scholz, D. Tigkas, Sensitivity of surface runoff to drought and climate change: Application for shared river basins, Water 6:10 (2014) 3033-3048.

IPCC, Climate Change 2013: The Physical Science Basis. Contribution of Working Group I to the Fifth Assessment Report of the IPCC, Stocker T.F. et al., (Eds.). Cambridge University Press, Cambridge, U.K., 2013.

IPCC, Climate Change 2014: Synthesis Report. Contribution of Working Groups I, II and III to the Fifth Assessment Report of the IPCC, Pachauri R.K. et al., (Eds.). IPCC, Geneva, Switzerland, 2014.

IPCC, Managing the Risks of Extreme Events and Disasters to Advance Climate Change Adaptation. A Special Report of Working Groups I and II of the IPCC, Field C.B. et al., (Eds.). Cambridge University Press, Cambridge, U.K., 2012, 582p.

Khalili D, Farnoud T, Jamshidi H, KamgarHaghighi AA, Zand-Parsa S. Comparability analyses of the SPI and RDI meteorological Drought indices in different climatic zones. Water Resources Management 2011; 25(6):1737-1757.

McKee T. B., N. J., Doesken and J., Kliest, 1993. The relationship of drought frequency and duration to time scales. In: Proceedings of the 8th Conference on Applied Climatology, 17-22 January, Anaheim, CA. American Meterological Society, Boston, MA. 179-184.

Shokoohi, A., R. Morovati, Basinwide comparison of RDI and SPI within an IWRM framework, Water Resour. Manage. 29:6 (2015) 2011- 2026.

Tigkas, D., H. Vangelis, G. Tsakiris, The RDI as a composite climatic index, Eur. Water 41 (2013) 17-22.

Tsakiris, G. (2004). Meteorological Drought Assessment. Paper prepared for the needs of the European Research Program MEDROPLAN (Mediterranean Drought Preparedness and Mitigation Planning), Zaragoza, Spain.

Tsakiris, G., Pangalou, D., and Vangelis, H. (2006). Regional Drought Assessment Based on the Reconnaissance Drought Index (RDI), Water Resources Management, 21, pp. 821-833.

Tsakiris, G., Vangelis, H. (2005). Establishing a drought index incorporating evapotranspiration. Eur Water 9-10:1-9.

World Meteorological Organization. Drought monitoring and early warning: Concepts, Progress and Future Challenges, WMO Report No. 1006. 2006; 26 p.

Zarch, M.A.A., B. Sivakumar, A. Sharma, Droughts in a warming climate: A global assessment of Standardized Precipitation Index (SPI) and Reconnaissance Drought Index (RDI), J. Hydrol. 526 (2015) 183195.

Zarch MAA, Hossein M, Mobin MH, Dastorani, MT, Kousari MR. Drought monitoring by Reconnaissance Drought Index (RDI) in Iran. Water Resources Management; 25:3485-3504.

\section{How to cite this article:}

Memon, A.V. and Shah, N.V. 2019. Assessment and Comparison of SPI and RDI Meteorological Drought Indices in Panchmahals District of Gujarat, India. Int.J.Curr.Microbiol.App.Sci. 8(08): 19952004. doi: https://doi.org/10.20546/ijcmas.2019.808.233 